\title{
An Empirical Study on the Non-Linear Relationship between the Performance of Funds and the Cash Flows of Funds
}

\author{
Feng Chen \\ Department of Finance, College of Economics, Jinan University, Guangzhou, China \\ Email: exnova@126.com
}

How to cite this paper: Chen, F. (2018) An Empirical Study on the Non-Linear Relationship between the Performance of Funds and the Cash Flows of Funds. American Journal of Industrial and Business Management, 8, 881-897.

https://doi.org/10.4236/ajibm.2018.84061

Received: March 19, 2018

Accepted: April 24, 2018

Published: April 27, 2018

Copyright $\odot 2018$ by author and Scientific Research Publishing Inc. This work is licensed under the Creative Commons Attribution International License (CC BY 4.0).

http://creativecommons.org/licenses/by/4.0/

(c) (i) Open Access

\begin{abstract}
This article takes 152 open-ended stock funds and partial stock funds established before the second quarter of 2015 as samples. Using the regression model of the non-balanced panel data fixed-effect model, this paper discussed the specific impact of the historical performance and other influencing factors on the purchase and redemption of investors from the first quarter of 2013 to the second quarter of 2017. And the nonlinear relationship between fund performance and capital flow is investigated by piecewise linear regression. The empirical results reveal that the fund's lagging quarterly performance has a positive impact on the funds flow in the next quarter. Investors generally chase performance rather than "reverse selection", and find that the relationship between historical performance and capital flow is non-linear. The fund flow has different sensitivity to outstanding performance fund, medium performance fund and poor performance fund. Fund flow is most sensitive to outstanding performance funds, followed by the medium performance fund, and insensitive to the poor performance funds. Finally, this paper uses the theory of "principal-agent" to analyze the results, and puts forward suggestions to improve the performance incentive mechanism of China's fund market.
\end{abstract}

\section{Keywords}

Fund Performance, Capital Flow, Nonlinear Relationship, Principal-Agent

\section{Introduction}

The development of the fund's investment in foreign countries has been more than one hundred years old. With its unique advantages of facilitating investment, expert management, diversification of risks and economies of scale, it has 
become a global investment mode. And it plays an important role in world financial markets. The development of investment funds in China is only close to 20 years old. After the Securities Commission of the State Council issued the "Measures for the Management of Securities Investment Funds" in November 1997, a genuine securities investment fund was created on March 27, 1998. As a popular investment product, it has been favored by investors and plays an important role in developing and stabilizing the securities market.

In September 2001, China's first open-ended fund, the Huaan Innovation Fund, was issued. After a short period of ten years, the open-end fund developed rapidly and its scale has far exceeded that of closed-end funds. According to Wind's statistics, as of December 2016, there are 120 fund management companies in China, and the securities investment fund market has coexisted 3675 funds. The cumulative net value of assets has reached RMB 9106 billion, and the fund's share has reached 872.129 billion, with a total of 1392 fund managers. In the continuous development of the fund industry, it is also facing increasingly fierce competition in the industry. Standing out from the crowd, fighting for more market share, capital inflows and creating more profits for the company have become the target of every fund company. On the other hand, how to identify the most valuable products in a wide range of fund products also tests the wisdom of investors.

In the fund market, investors will refer to the fund's historical performance to make a purchase or redemption fund decision. The fund's performance will play a signal role in the market competition. China's open-end funds have a free purchase and redemption mechanism. Rational investors can evaluate fund managers' ability according to fund performance, buy funds with good performance, and redeem funds with poor performance. The "pursuit of performance" rational behavior of investors can enable funds with good performance to obtain capital inflows, increase in scale, and increase management fee income. Funds with poor performance will encounter outflows of funds, scale reduction, and decline in management fee income. The positive feedback between fund performance and capital inflow can generate implicit incentives for fund managers. The effectiveness of this positive feedback also relates to fund governance and investor interest protection. On the contrary, if the negative relationship between "fund flow-performance" exists, the "paradox of fund redemption" exists. This will "incentivize" fund managers to pursue the maximization of management fees at the expense of the fund's return on investment, thus seriously damaging the interests of investors. It will seriously damage the interests of investors and cause the "Bad money drives out good money" in fund market, which ultimately has a major negative impact on the sound development of China's fund market [1].

The main contributions of this article are as follows. First, this article uses normative research methods to enrich the research literature on the relationship between capital flow and fund performance, revealing that there is no "paradox 
of fund redemption" phenomenon in China's fund market. It supports the conclusion of Xiao Jun et al. (2011) and Feng Xunan et al. (2013). Overall, our fund investors are still "chasing performance" instead of "reverse selection" [1] [2]. Secondly, this paper confirms the non-linear relationship between funds flow and fund performance in China's fund market. That is, the top-ranking "star fund" can attract excess capital inflows, and the bottom-ranked funds have not been sold to a corresponding degree.

The article is organized as follows. The second part is based on the academic achievements, focusing on the relationship between the Fund's historical performance and cash flow. The third part describes the data source, variable definition, descriptive statistics and research methods. The fourth part is empirical results, discussing the historical performance and other factors on the impact of funds cash flow, and further studying the non-linear relationship between historical performance and capital flow of fund. The fifth part is robustness check. The sixth part is conclusions and advice.

\section{Literature Review}

The Western market economy developed earlier and the capital market is highly developed. The earliest investment funds originated in the United Kingdom and became prevalent in the United States after World War I. In the United States, mutual funds became a favorite choice for household financial management. The research of mutual fund by western scholars has been carried out earlier and has achieved a great deal of scientific research results. The research in foreign countries mainly refers to the fund research for the American Mutual Fund market. The factors that influence investors' choice mainly revolve around the relationship between fund performance and capital flow (Abbreviated as PFR).

Spitz (1970) based on the analysis of the performance and cash flow correlation of 20 mutual funds within the US stock market from 1960 to 1967. After adding the disposable income variable to the model, he found that the fund's performance has a positive effect on the flow of funds [3]. Earlier studies of PFR scholars also included Smith's (1978) use of risk-adjusted returns to rank the fund's performance ordinals and found that three years of the eight-year sample exhibited a positive PFR correlation [4]. Ippolito (1992) studied 143 US open-end funds from 1965 to 1984, using risk-adjusted excess returns as performance indicators. It further confirms the positive impact of the Fund's historical performance on the inflow of funds, and finds that the capital inflow with better performance funds is faster than the fund outflow rate of poor performance funds [5]. Sirri \& Tufano (1998) also confirmed the positive correlation between historical fund performance and capital inflows and PFR non-linearity. Funds with outstanding performance will be sought after by investors and will receive more capital inflows in the next period. However, funds with poor performance will not suffer the same degree of investor abandonment. The outflow of funds in the next period is not obvious [6]. Brown, Harlow \& Starks (1996) 
believe that investors are optimistic about the follow-up performance of poor funds. The PFR mechanism was similar to the call option, which was a convex function [7]. Fant \& O'Neal (2000) analyzes the more apparent PFR asymmetry in subsamples of US mutual funds of the market from 1978 to 1987 and from 1988 to 1997. This paper uses the raw return and Jensen Alpha as performance indicators to perform a piecewise linear regression. And establish an elastic indicator of fund flow on fund performance. The study found that the flow of funds does not increase the elasticity of the pursuit of fund performance. A large amount of capital inflows is merely due to the increase in the total funds in the fund market, and not to the increase in investor interest in the fund. In summary, foreign scholars have a more consistent view of the fund's PFR, and generally believe that the graph between them shows a positive convex curve [8]. There are also pointed out that the non-linearities of the fund PFR include Guercio \& Tkac (2001), Berk \& Green (2004), Lynch \& Musto (2003), etc. and analyze this phenomenon from different perspectives [9] [10] [11].

Compared to the West, the time for the development of the Chinese financial market is short, and the development of public funds is less than 20 years. There are few samples in early research on PFR, and the phenomena found in PFR studies are very different from abroad. Liu Zhiyuan and Yao Yi (2005) found "the paradox of fund redemption", a negative correlation between fund performance and capital inflow, in the regression of 17 open-end fund panel data and cross-sectional data from 2003 to 2004 in China [12]. Li Yao and Yu Jinje (2004), based on a sample of 17 open-ended funds in 2003, also found that the annual net cumulative growth rate was higher, and these redemption rates, along with the increase, confirmed "the paradox of fund redemption" [13]. Lu Rong (2007) analyzed "the paradox of fund redemption" of China's fund market through the regression of 14 partial open-ended fund-oriented panel data in China, and found that contrary to the relationship between foreign fund performance and capital inflow, China's PFR was presented Negative correlation, and pointed out that investors tend to redeem funds with good historical performance, large fluctuations in performance, low dividends, and large scale [14]. Shan Liwei and Shen Yu (2013) used the open-ended fund from 2005 to 2010 as a sample, and added the fund marketing indicators to the research PFR model. The index includes the number of marketing agencies, the number of marketing outlets, and the number of professional marketing personnel. The study found that fund marketing has a positive impact on the net inflow of funds, so even if the fund performance is poor, as long as there is sufficient investment in marketing, it will attract large amounts of capital inflows [15]. Yu Honghai, Lu Rong and Xu Longbing (2014) used the sample of 76 stocks and hybrid funds that were actively split between 2006 and 2008 as a sample. The logit regression found that the split of the fund increased the demand of individual investors and caused a large inflow of funds [16].

In recent years, some scholars have questioned the "paradox of fund redemp- 
tion".

Peng Hui et al. (2012) took partial open-ended fund funds from 2005 to 2008 as a sample, and regressed monthly panel data. It was empirically found that the "paradox of fund redemption" had fund current performance, but it does not exist for historical performance. The better the fund's historical performance, the more it can attract capital inflows, and the SVAR analysis indicates that there is no disposal effect for investors to redeem. The "paradox of fund redemption" is due to the abnormal behavior of investors' purchase [17]. Xiao Jun (2011) selected 204 stock open-end funds as a sample and established a Piecewise linear regression fixed-effect model. He concluded that the fund's lagging annual rate of return has a significant positive impact on the net flow of funds and believes that the "paradox of fund redemption" is only an illusion [1]. Luo Yulin et al. (2012) pointed out that the "disposal effect" of investors in the study of bond-based open-end funds between 2006 and 2010 was to sell high-yield funds and buy low-yielding funds. There is no "paradox of fund redemption" [18]. Feng Xunan and Li Xinyu (2013) applied the quantile regression method for the open-end stock funds from 2005 to 2011 as a sample, introduced the proxy variable of participation costs, further analyzed the sensitivity of funds flow-performance, and found that China's funds Investors not only chase merit funds but also abandon bad funds [2].

In addition to fund performance, scholars have also conducted research on other factors that affect the flow of funds. Including market performance, the fund's own characteristics such as fund size, fund age, fund rate, and dividends are also factors that affect investor selection. Fortune (1998) research on the earnings of S\&P 500 and the long-term treasury bonds through VAR method. It is found that the realized securities proceeds have positive effect on the inflow of equity funds and bond funds, and the inflow of capital will have positive effect on the stock returns [19]. Edelen (1999) studies the Nasdaq daily stock returns and the corresponding daily fund flow of 424 equity funds from February 1998 to June 1999 in the United States. The positive effects of realized equity gains on capital inflows from equity funds and bond funds are found, and capital inflows also have a positive impact on the return on securities [20]. Zeckhauser, Patel \& Hendricks (1991), in a sample of commission-free funds from 1975 to 1987, pointed out the positive linear relationship between capital flows and fund size [21]. Sirri \& Tufano (1998) found that fund size, transaction costs, fund establishment, and dividends have a significant impact on financial flows. The study found that the flow of funds with lower transaction costs was more, but if the increase in transaction costs did not lead to a decline in capital inflows. The author pointed out that increased transaction costs may be spent on marketing. At the same time, it has also been found that long-established and larger-scale funds have a more brand-like effect and are more likely to attract investors' attention [6]. Similarly Fant \& O'Neal (2000) has a positive impact on the fund's size and fund-setting time on the capital inflow [8]. 
In the Chinese market, Liu Zhiyuan et al. (2005) have pointed out that the more dividends the more the fund redemption rate is lower, the less obvious the outflow [12]. Lu Rong et al. (2007) found that the stability of returns, fund size, and dividends all affect investors' choices. It is found that investors tend to redeem funds with large returns, low dividends, and large scale [14]. Xiao Jun et al. (2011), Shan Liwei and Shen Yu (2013) pointed out that investors prefer new, smaller and more dividends funds [1] [15]. Li Ke and Lu Rong (2011) analyzed the phenomenon of large-scale dividend distribution of open-end funds from 2006 to 2009. After empirical research, it was found that after a large percentage of dividends, the net fund flow increased more than twice and the marketing expenses also increased significantly [22].

In the past, the research on the PFR of fund market in China has mainly taken the balance panel data as sample, resulting in too little sample size, too short study time, and affecting the effectiveness of the results. Based on the research methods of foreign mainstream literatures, this paper makes up and perfects the insufficiency of domestic research methods and sample selection methods for FPR. Using the unbalanced panel data from the most recent observational samples from 2013 to 2Q2017, we tests whether investors are chasing historical performance or "adverse selection" in making investment decision, and further analyzing the asymmetry of PFR.

\section{Data and Empirical Methodology}

\subsection{Data}

This article selects 152 funds from open-end equity funds and partial stock funds established before the third quarter of 2015 as samples. The number of funds in each quarter is shown in Table 1. Similar to international literature, this article only analyzes funds in the domestic market, so the sample does not contain QDIIs that invest in overseas markets. As index fund investment is passive, index funds are not included in the sample. The time interval ranges from the first quarter of 2013 to the second quarter of 2017, with a total of 18 quarters of study period. The time frequency of the study is quarterly data. In summary, the data structure of this paper is unbalanced panel data with $\mathrm{n}=13$ and $\mathrm{T}=18$. The study of the original data includes the net assets at the end of the quarter, quarterly dividends, years of establishment, volatility of the fund's return, fund size, and fund company size data mainly from the WIND database.

Interpreted variables: the definition of net flow of funds $\mathrm{Flow}_{i, t}$ reference Xiao Jun (2011), Sirri \& Tufano (1997) [1] [6] using:

$$
\text { Flow }_{i, t}=\frac{T N A_{i, t}-T N A_{i, t-1} \times\left(1+R_{i, t}\right)}{T N A_{i, t-1}}
$$

where $T N A_{i, t}$ is the total net asset value of fund $i$ in season $t, R_{i, t}$ is the return rate of fund $i$ in season $t$, and dividend reinvestment is included.

Explanatory variables: The fund performance indicators selected in this paper 
Table 1. Number of funds in each quarter.

\begin{tabular}{|c|c|}
\hline Year (Quarter) & Number of funds \\
\hline 2013Q1 & 81 \\
\hline 2013Q2 & 83 \\
\hline 2013Q3 & 86 \\
\hline 2013Q4 & 88 \\
\hline 2014Q1 & 92 \\
\hline 2014Q2 & 93 \\
\hline 2014Q3 & 97 \\
\hline 2014Q4 & 99 \\
\hline 2015Q1 & 105 \\
\hline 2015Q2 & 115 \\
\hline 2015Q3 & 142 \\
\hline 2015Q4 & 152 \\
\hline 2016Q1 & 152 \\
\hline 2016Q2 & 152 \\
\hline 2016Q3 & 152 \\
\hline 2016Q4 & 152 \\
\hline 2017Q1 & 152 \\
\hline 2017Q2 & 152 \\
\hline
\end{tabular}

are:

$R_{i, t-1}:$ Lag of a quarter of the raw return (including dividend reinvestment)

$$
R_{i, t}=\frac{P_{i, t}+\text { divident }_{i, t}-P_{i, t-1}}{P_{i, t-1}}
$$

where $P_{i, t}$ is the net asset value of the fund $i$ at the end of period $\mathrm{t}$, and divident is the unit equity dividend of fund $i$ at $t$ period

At the same time, the market model adjusted return Jensen Alpha as a robustness test, the calculation method is:

$$
\begin{gathered}
R_{i, t}-R F_{t}=\alpha_{i}+\beta_{i, R M R F} \times R M R F_{t}+e_{i, t} \\
\alpha_{i, t}^{\text {Jensen }} \equiv \alpha_{i}+e_{i, t}
\end{gathered}
$$

For each fund, using its historical data in the study, estimate $\beta_{i, R M R F}$ according to Equation (3), and find that $\alpha_{i, t}^{\text {Jensen }}$ can be obtained by combining Equation (4).

Control variables:

Fund size- $\ln \left(T N A_{i, t-1}\right)$. The same amount of fund flow affects the small fund much more than the big fund, so it is similar to Sirri and Tufano (1998) [6]. The natural capital of the fund at the end of the previous quarter was $\ln \left(T N A_{i, t-1}\right)$ as the control variable of the fund size.

Fund age $-\ln \left(A g e_{i, t-1}\right)$. DelGuercio and Tkac (2001) have found that the number of years of fund establishment is negatively related to financial flows [9]. 
Therefore, referring to DelGuercio and Tkac (2001), the natural logarithm $\ln \left(\right.$ Age $\left._{i, t-1}\right)$ of the fund's life span is used as a control variable to control the potential impact of fund age differences on financial flows [9].

Fund family size- $\ln \left(\right.$ FamilySize $\left._{i, t-1}\right)$. Funds from the big family are more susceptible to investor attention, making it easier to attract capital. This is evidenced by Sirri and Tufano (1998) [6]. Therefore, we use the natural logarithm $\ln \left(\right.$ FamilySize $\left._{i, t-1}\right)$ manage the total assets to measure the family size.

Standard deviation of fund returns- $S t d_{i, t-1}$. Foreign research shows that the greater the fund's risk, the smaller the net inflow of funds, in order to control the impact of fund risk on investors' behavior.

Return on Market-Return ${ }_{t-1}^{\text {Market }}$. The performance of the market will affect the income of various types of financial products, directly related to the performance of the fund, and it is also an important aspect affecting fund flow. Domestic and foreign market performance on the impact of the stock market on fund flow mainly in the stock market return, liquidity, volatility and so on. Therefore, this article takes the Shanghai Composite Index quarterly yield as the market rate of return.

Annual dummy variable-Year dummy. In addition, this article adds annual dummy variables to control the impact of differences in market conditions for different years on the flow of funds.

The summary statitics of the main variables is shown in Table 2 .

\subsection{Empirical Methodology}

Based on the related research of overseas literature, the measures of fund returns can be either ordinal measures or cardinal measures. Ordinal measure of return intuitively reflects the ranking information of fund performance, so it is more valued by investors, and can better explain the change of fund scale. In addition, ordinal returns can also reduce the impact of abnormal returns on empirical results. This article refers to Xiao Jun and Shi Jin (2011), Feng Xunan et al. (2013) Fund performance using Ordinal Measure for analysis [1] [2].

The ordinal measure is defined as: In each period, the sample fund is sorted by the performance of the lag quarter from small to large, The lowest performance

Table 2. Summary statistics.

\begin{tabular}{cccccc}
\hline Variable & Obs & Mean & Std.Dev & Min & Max \\
\hline Flow $_{i, t}$ & 1993 & 0.050 & 0.720 & -1.069 & 12.752 \\
Rank $_{i, t-1}$ & 1993 & 0.5 & 0.291 & 0 & 1 \\
$\ln \left(\right.$ TNA $\left._{i, t-1}\right)$ & 1993 & 1.875 & 1.404 & -2.721 & 4.742 \\
$\ln \left(\right.$ FamilySize $\left._{i, t-1}\right)$ & 1993 & 6.302 & 1.227 & 0.744 & 9.392 \\
Std $_{i, t-1}$ & 1993 & 0.013 & 0.0110 & 0 & 0.0539 \\
Market $_{t-1}^{\text {Retur }}$ & 1993 & 0.0341 & 0.139 & -0.286 & 0.368 \\
$\ln \left(\right.$ Age $\left._{i, t-1}\right)$ & 1993 & 4.173 & 3.054 & 0 & 14.183 \\
\hline
\end{tabular}


of the fund corresponding to the ordinal measure of 0 , the highest is 1 , the rest in the $(0,1)$ interval evenly distributed.

In order to test the relationship between capital flow and performance, according to the research literatures at home and abroad, this paper establishes the following regression model with the rate of return of the lagging quarter as the explanatory variable.

$$
\text { Flow }_{i, t}=\alpha+\beta \text { Rank }_{i, t}+\gamma \text { Controls }+\varepsilon_{i, t}
$$

In model (5), the explained variable $F l o w_{i, t}$ is the fund flow of fund $i$ in t quarter. The explanatory variable $\operatorname{Rank}_{i, t}$ is the ordinal measure of fund $i$ in $t$ quarter. Controls represents other control variables that may affect the funds flow of the fund. In order to test whether there is a nonlinear relationship between flow and historical performance, refer to the existing literature Sirri \& Tufano (1998); Xiao Jun and Shi Jin (2011) to establish the following piecewise linear Regression model [1] [6]:

$$
\begin{aligned}
& \text { Flow }_{i, t}=\alpha_{i}+\beta_{1} \text { Rank }_{i, t-1}^{\text {Top }}+\beta_{2} \text { Rank }_{i, t-1}^{\text {Middle }}+\beta_{3} \text { Rank }_{i, t-1}^{\text {Bottom }}+\gamma \text { Controls }+\varepsilon_{i, t} \\
& \operatorname{Rank}_{i, t}^{\text {Bottom }}=\operatorname{Min}(\text { Rank, } 0.1) \\
& \operatorname{Rank}_{i, t}^{\text {Middle }}=\operatorname{Min}\left(\operatorname{Rank}-\operatorname{Rank}^{\text {Bottom }}, 0.8\right) \\
& \operatorname{Rank}_{i, t}^{\text {Top }}=\operatorname{Min}\left(\text { Rank }- \text { Rank }^{\text {Bottom }}-\operatorname{Rank}_{i, t}^{\text {Middle }}, 0.1\right)
\end{aligned}
$$

Among them, $\alpha_{i}$ used to measure the fixed effect of the fund, $\beta_{i}$ response to the financial flow of the historical performance of the sensitivity, Rank $k_{i, t}^{\text {Top }}, \operatorname{Rank}_{i, t}^{\text {Top }}$ and $\operatorname{Rank}_{i, t}^{\text {Bottom }}$ represent the top 10\% funds, the top $10 \%-90 \%$ funds and ranked after $10 \%$ funds. The fund's rank is defined as follows.

\section{Empirical Results}

\subsection{Preliminary Exploration of the Relationship between Fund Performance and Capital Flow}

It can be seen from Table 3 that the coefficient of Rank is significantly positive, indicating that the lagging quarterly return has a significant positive effect on the fund flow. That is, the better the performance in the previous quarter, the more money flows in the next quarter. Domestic scholars such as Liu Zhiyuan and Yao Xin (2005) and Lu Rong (2007) found that investors chose redemption when their fund performance was good, and they called it a "paradox of fund redemption" [12] [14]. In contrast, the empirical results of this paper suggest that there is no "paradox of fund redemption" in China's fund market. This is consistent with the research results of Xiao Jun et al. (2011) and Feng Xunan et al. (2013), indicating that Chinese investors as a whole are chasing performance rather than "reverse selection". The so-called "paradox of fund redemption" is just an illusion [1] [2]. Based on the performance of raw return and Jensen $\mathrm{Al}$ pha, the coefficients are positive and both are at a significant $1 \%$ level, which indicates that the conclusion of this model has good robustness. 
Table 3. Fund performance and capital flow.

\begin{tabular}{ccc}
\hline Model & Raw return & $\alpha^{\text {lensen }}$ \\
\hline Rank & $1.277^{* * *}$ & $1.280^{* * *}$ \\
& 7.99 & 7.32 \\
$\ln ($ TNA $)$ & $-0.312^{* * *}$ & $-0.310^{* * *}$ \\
& -9.24 & -9.14 \\
$\ln ($ Family Size $)$ & 0.027 & 0.0281 \\
& 0.63 & 0.67 \\
Std & -2.242 & -2.736 \\
& -0.67 & -0.81 \\
Market & $-0.854^{* * *}$ & $0.281^{* * *}$ \\
& -4.01 & 2.14 \\
$\ln ($ Age $)$ & $0.136^{*}$ & 0.136 \\
Year Dummy & 1.96 & 1.92 \\
Observations & Yes & Yes \\
$R^{2}$ & 1993 & 1993 \\
\hline
\end{tabular}

This table examines the overall relationship between fund performance and capital flow, based on the fixed-effect model. The result of the Hausman test is zero, which supports the fixed effect model and negates the stochastic effect model. The explanatory variable is the rank of the raw return of the fund lagging one quarter, while the rank of Jensen Alpha as a robustness test. The first number in each cell is the regression coefficient and the value in parentheses is the associated $\mathrm{t}$-value. ${ }^{* * *}$ indicates $\mathrm{p}<0.01{ }^{* *}$ indicates $<$ $0.05 *$ indicates $\mathrm{p}<0.10$.

\subsection{Further Analysis of PFR}

According to the literature Feng Xunan (2013) pointed out that the performance of China's fund market poor funds, performance of general funds, and merit funds have a non-linear impact on investors [2]. In order to further analyze the performance of funds and the sensitivity of fund flow, we divide the performance of each quarter (raw return including dividend reinvestment) into 20 groups from the largest to the smallest. The ordinate is the net fund of the corresponding group in the next quarter. The ordinate is the average of the net flow of funds in the next quarter.

It can be seen that the reaction of fund flow to the previous quarter's performance varies according to the performance. In the fund with excellent performance $(10 \%)$ in the previous quarter, the flow of funds in the next quarter increased significantly. When the performance is poor and the performance is normal, the financial flow is not sensitive to the performance. The findings in Figure 1 and the conclusions of Liu Zhiyuan and Yao Yi (2005), Li Yao and Yu Jinjie (2004), and Lu Rong et al. (2007) are also quite different [12] [13] [14]. They are mainly based on the stock bear market period (2002-2005). Their discovery is that the higher the performance of the fund, the more investors are inclined to redeem. Unlike them, our long sample interval includes not only the stock bear market year (2013-2014) but also the bull market year (2014-2015). 


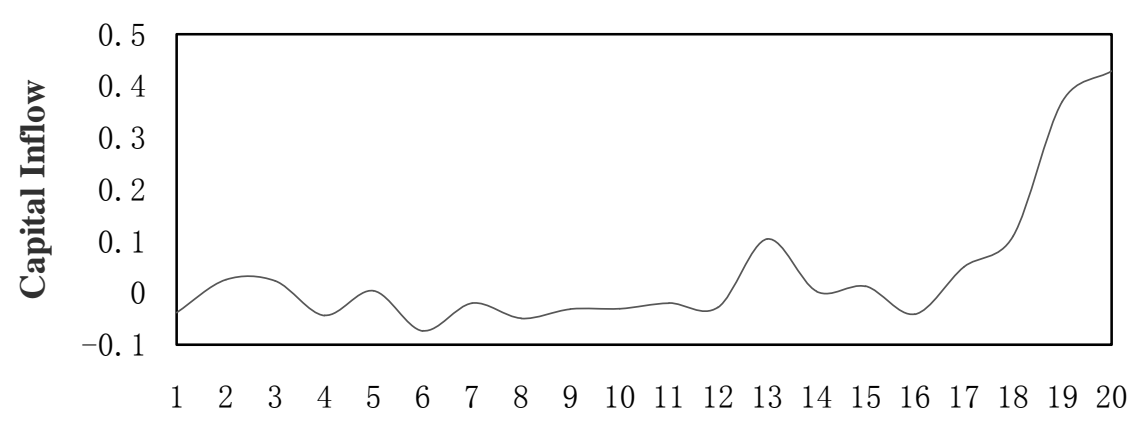

\section{Rank}

Figure 1. The rank and capital inflow.

This is consistent with the research findings of Feng Xunan et al. (2013) on open-end funds in China from 2005 to 2011. This shows that investors have a strong preference for buyouts and redemptions on merit funds. In contrast, funds with medium-term performance are less sensitive to the results of the previous period. The difference from Feng Xunan is that the study found that the deterioration of the performance of poor performance funds has not been punished accordingly, and investors have not shown strong selling behavior.

According to Model (6), the following is a further study of the relationship between fund performance and fund flow, based on piecewise linear regression. The model examines the impact of ranking bottom funds, ranking medium funds, and ranking top funds on the capital flow of funds.

The regression results of Model (6), as shown in Table 4, can be found that the coefficients of $\operatorname{Rank}^{T o p}$ and Rank ${ }^{\text {Middle }}$ are positive, while the rank bottom coefficients are negative but not significant, which shows that the sensitivity of PFR is characterized by stages. Combining Chart 1 and Table 2, we can see that the pre-performance of the merit fund and the middle performance fund has a positive impact on the next-period flow, while the performance of the ranking bottom fund's previous period has no obvious effect on investors. Among them, Rank $^{\text {Top }}$ coefficient is the largest and Rank $k^{\text {Middle }}$ coefficient is the second. This shows that investors are most sensitive to the ranking top funds, while the sensitivity to the funds with ranking medium funds is second, and the performance of the fund is not sensitive to ranking bottom funds. This shows that the PFR in the Chinese fund market also appears asymmetric. Therefore, this article can draw the following conclusion: When the fund's performance is good, the slight increase in the previous period's performance can bring more capital inflows; when the fund's performance is normal, it needs a large increase in performance to bring in capital inflows. However, when the performance of the fund is poor, investors are not sensitive to the performance. Interestingly, this finding is different from the fact that Feng Xunan et al. (2013) found that poor performance 
Table 4. The nonlinear relationship between fund performance and capital flow.

\begin{tabular}{|c|c|c|}
\hline Model & Raw return & $\alpha^{\text {Jensen }}$ \\
\hline \multirow{2}{*}{ Rank $k^{\text {Bottom }}$} & -0.951 & -0.869 \\
\hline & -1.52 & -1.5 \\
\hline \multirow{2}{*}{ Rank $^{\text {Middle }}$} & $1.186^{\star *}$ & $1.064^{* *}$ \\
\hline & 2.08 & 1.98 \\
\hline \multirow{2}{*}{$\operatorname{Rank}^{T o p}$} & $5.76^{* * *}$ & $5.640^{\star * *}$ \\
\hline & 6.56 & 5.51 \\
\hline \multirow{2}{*}{$\ln (T N A)$} & $-0.290^{\star * \star}$ & $-0.293^{* * *}$ \\
\hline & -8.71 & -8.64 \\
\hline \multirow{2}{*}{$\ln ($ Family Size $)$} & 0.062 & 0.062 \\
\hline & 1.39 & 1.35 \\
\hline \multirow{2}{*}{ Std } & -1.995 & -2.474 \\
\hline & -0.60 & -0.74 \\
\hline \multirow{2}{*}{ Market Return } & $0.340^{* * *}$ & $0.322^{* * *}$ \\
\hline & 2.58 & 2.45 \\
\hline \multirow{2}{*}{$\ln (A g e)$} & 0.101 & 0.110 \\
\hline & 1.45 & 1.54 \\
\hline Year Dummy & Yes & Yes \\
\hline Observations & 1993 & 1993 \\
\hline$R^{2}$ & 0.082 & 0.081 \\
\hline
\end{tabular}

This table uses the results of a fixed-effects panel regression. The first number in each cell is the regression coefficient and the value in parentheses is the associated $t$-value. ${ }^{\star * *}$ indicates $\mathrm{p}<0.01{ }^{\star *}$ indicates $<0.05$ *indicates $\mathrm{p}<0.10$.

funds are subject to strong investor selling [2]. Consistent with the evidence from markets in the United States of Sirri and Tufano (1998), in their sample, the merit fund caused over-subscription of investors, and the poor performance fund did not receive the same degree of redemption [6].

From Table 4, it can be found that the fund size has a significant negative impact on the fund flow in other influencing factors, indicating that investors prefer funds with a relatively small fund size. The greater the size of the fund, the smaller the net fund flow of the fund. This is consistent with the findings of $\mathrm{Lu}$ Rong (2007), Xiao Jun et al. (2011) and Feng Xunan et al. (2013) [1] [2] [14]. The $S t d$ coefficient is not significant, indicating that the Risk of the fund has no significant impact on the fund flow. This is contrary to the literature study abroad, and it is consistent with Xiao Jun et al. (2011) [1]. It shows that China's fund investors are not sensitive to risks. Relatively speaking, they pay more attention to performance rather than risk. Xiao Jun (2011) points out that investors value performance, while relative neglect of risk may lead to fund managers' risk-taking behavior [1]. The coefficient of Market $^{\text {Return }}$ is significantly positive, indicating that the market performance has a positive effect on the flow of funds. When the stock market performs well, more investors participate in the invest- 
ment in the fund market, thereby bringing capital inflows to the fund market. When the stock market performance is poor, some investors choose to redeem funds or leave the market. This finding is consistent with the results of Feng Xunan et al. (2013) [2].

\section{Robustness Check}

In the empirical part above, the raw return and Jensen's excess return were selected as metrics of the fund's performance, which significantly improved the reliability and robustness of the paper.

Considering that the past fund flow of the fund may have an impact on the future fund flow, we added one lagging period's Flow $_{i, t-1}$ as one of the explanatory variables in the basic model (6). Build a Dynamic Panel Regression Model for Robustness Testing. In order to solve the endogeneity problem of explanatory variables in the dynamic model, we adopt a two-step systematic generalized moment estimation method. The results are shown in Table 5.

Table 5. Robustness test results.

\begin{tabular}{|c|c|}
\hline Model & Raw return \\
\hline \multirow[b]{2}{*}{ Flow $_{i, t-1}$} & 0.080 \\
\hline & 0.003 \\
\hline \multirow{2}{*}{$\operatorname{Rank}^{\text {Bottom }}$} & -1.294 \\
\hline & -1.63 \\
\hline \multirow{2}{*}{ Rank $^{\text {Middle }}$} & $1.515^{\star *}$ \\
\hline & 2.04 \\
\hline \multirow{2}{*}{$\operatorname{Rank}^{T o p}$} & $5.334^{* * *}$ \\
\hline & 4.36 \\
\hline \multirow{2}{*}{$\ln (T N A)$} & $-1.388^{* * *}$ \\
\hline & -8.43 \\
\hline \multirow{2}{*}{$\ln ($ Family Size $)$} & 0.124 \\
\hline & 1.17 \\
\hline \multirow{2}{*}{ Std } & -1.309 \\
\hline & 0.32 \\
\hline \multirow{2}{*}{ Market $^{\text {Return }}$} & $0.886^{* * *}$ \\
\hline & 3.19 \\
\hline \multirow{2}{*}{$\ln (A g e)$} & 0.085 \\
\hline & 0.52 \\
\hline Year Dummy & Yes \\
\hline Observations & 1993 \\
\hline Sargan test & 0.515 \\
\hline$A R(1)$ & 0.003 \\
\hline$A R(2)$ & 0.735 \\
\hline
\end{tabular}

The $\mathrm{P}$ value of Sargan test is greater than 0.10 , indicating that the overall construction of the instrument variable is effective. The p-values of $A R(1)$ and $A R(2)$ indicate that there are only first-order correlations and no second-order correlations for the residuals after difference, and there is no sequence correlation in the original model error term. The first number in each cell is the regression coefficient and the value in parentheses is the associated t-value. ${ }^{* * *}$ indicates $\mathrm{p}<0.01^{* *}$ indicates $<0.05^{*}$ indicates $\mathrm{p}<0.10$. 
In Table 5, the sign and significance of the key variables Rank ${ }^{\text {Bottom }}$, Rank $k^{\text {Middle }}$ and $\operatorname{Rank}^{T o p}$ have not changed, indicating that the conclusions in this paper have good robustness. At the same time, the regression coefficient of Flow $_{i, t-1}$ is minimal and not significant, indicating that the dynamic panel model is not better than the fixed effect model. This also proves that there is no missing variable problem in the fixed effect model used above, and the model setting is reasonable.

\section{Conclusions and Advice}

This article studies 152 open-end stock funds and partial stock funds from the first quarter of 2013 to the second quarter of 2017 as research samples, and uses panel fixed-effect models to analyze the relationship between the performance of funds and the cash flow of funds. The main conclusions are listed as bellows: Chinese investors have shown overall performance in purchasing funds instead of "opposite choices", which shows that the overall trend of investors in China is rational and conducive to the stable and healthy development of China's financial market. Second, this paper finds that there is also a non-linear relationship between the performance of funds and the cash flow of funds in China's fund market. That is to say, the "star fund" that ranks high in performance can attract excessive capital inflows. At the same time, the investors prefer small-scale funds, and pay more attention to the performance of funds but ignore the risks of funds.

Based on the above conclusions, this study provides the following implications and practical significance:

First of all, China's Securities Investment fund is based on modern trust relationship on the basis of the contract (contract type) fund. As the main parties of the Fund contract, there is a "principal-agent" cooperative relationship between the Fund investor (client) and the fund Management Company (agent), which is behind the fund assets "ownership" and "management rights". Similar to the separation of "ownership" and "operation right" of the stock company, and the "principal-agent" problem of shareholders and management, the separation of "ownership" and "management power" of fund assets may lead to potential conflict of interest between fund investors and fund management companies. In other words, the objective functions of the "ownership" and "management power" are not naturally consistent: the investor pursues the maximization of wealth (or utility), and the fund management company pursues the maximization of management fee income.

Under the agent investment model of the fund industry, for the purpose of maximizing self-interest, the goal of maximizing the income of the fund management company may be above the target of maximizing investor wealth, which means that the income growth of the fund management company may be the loss of investor wealth which is at the expense of the investor. It should be pointed out that since the management fees of China's securities investment 
funds generally adopt a fixed-rate payment model, the goal of maximizing the interests of fund management companies can be regarded as maximizing the scale of assets pursuing management.

According to the "consignment-agent" theory, only by establishing an effective incentive mechanism and motivating the fund management company to take actions aimed at maximizing the interests of investors, can we minimize the conflict of interest between the fund investor and the fund management company. According to the empirical results of this paper, we can infer that the combination of the "pursuit of performance" behavior of fund investors and the goal of maximizing asset size by fund management companies can generate positive incentive mechanisms that effectively reduce the conflict of interest between the two theories.

This endogenous positive incentive mechanism can be described as follows: Fund performance is significantly positively correlated with the net fund flow, which means that investors will "reward and punish" according to the performance of fund, and rising fund performance will attract incremental capital inflows. The expansion of the size of fund assets will lead the increase in management fee income; conversely, a decline in the fund's performance will lead to shrinking asset size and decrease in management fee income. This implies a positive feedback relationship between fund performance and fund management company income. Obviously, this positive feedback relationship will motivate fund management companies to work hard to increase the return on investment of funds in order to pursue the growth of fund assets. It can be inferred that the fund management company can achieve the goal of maximizing the scale of assets while maximizing the investor's wealth. In other words, investors and fund management companies can achieve a win-win situation. There is no doubt that this endogenous positive incentive mechanism can not only reduce the conflict of interest between fund investors and fund management companies, but also promote the survival of the fittest in China's fund market, and can be an important "base stone" for the sound development of the fund market.

Secondly, securities regulatory authorities should strengthen the supervision of high-risk investment behaviors of funds, and help investors establish risk-matching investment ideas by strengthening investor education, so as to effectively limit the moral risk behavior of fund management companies (fund managers). Compared with the U.S. mutual fund market, China's fund market has a short history of development. Individual investors with immature investment ideas occupy the largest share of the market. Our research shows that domestic investors tend to pay more attention to rewards and relatively ignore risks. This irrational investment behavior "incentivizes" fund management companies (fund managers) to adopt high-risk radical investment strategies to pursue high returns. Therefore, supervisory authorities should strengthen the supervision of high-risk investment activities of the fund. For example, the frequency of fund short-term trading can be reduced by setting the upper limit of 
the turnover rate. Furthermore, the supervisory authority should also vigorously promote the education of fund investors, help fund investors establish investment concepts that match risk and return, change only the inherent thinking of rewards regardless of risk, and restrict the moral risk behavior of fund managers from the source, promoting the performance of incentive mechanism.

Finally, for fund management companies, it is necessary to strengthen internal governance of the company and strive to improve the performance of the fund so as to attract more investors to purchase. Fund management companies should strengthen the level of investment and research, create long-term star brands by increasing the sustainability of the performance of star funds, and stimulate the "star funds" effect of the fund market, so as to more effectively exert the positive incentive effect of performance incentives.

\section{References}

[1] Xiao, J. and Shi, J. (2011) Fund Performance and Fund Flow: Does the "Redemption Vision" Exist in China's Fund Market? Economic Research, No. 1, 112-125.

[2] Feng, X.N. and Li, X.Y. (2013) Participation Costs, Fund Performance and Investor Choices. Management World, No. 4, 48-58.

[3] Spitz, E. (1970) Mutual Fund Performance and Cash Inflows. Applied Economics, 2, 141-145. https://doi.org/10.1080/00036847000000023

[4] Smith, K.V. (1978) Is Fund Growth Related to Fund Performance? Journal of Portfolio Management, 4, 49-54. https://doi.org/10.3905/jpm.4.3.49

[5] Ippolito, R.A. (1992) Consumer Reaction to Measures of Poor Quality: Evidence from the Mutual Fund Industry. Journal of Law \& Economics, 35, 45-70.

https://doi.org/10.1086/467244

[6] Sirri, E.R. and Tufano, P. (1998) Costly Search and Mutual Fund Flows. Journal of Finance, 53, 1589-1622. https://doi.org/10.1111/0022-1082.00066

[7] Brown, K.C., Harlow, W.V. and Starks, L.T. (1996) Of Tournaments and Temptations: An Analysis of Managerial Incentives in the Mutual Fund Industry. The Journal of Finance, 51, 85-110. https://doi.org/10.1111/j.1540-6261.1996.tb05203.x

[8] Fant, L.F. and O’Neal, E.S. (2000) Temporal Changes in the Determinants of Mutual Fund Flows. Journal of Financial Research, 23, 353-371. https://doi.org/10.1111/j.1475-6803.2000.tb00747.x

[9] Del Guercio, D.G. and Tkac, P. (2001) Star Power: The Effect of Morningstar Ratings on Mutual Fund Flows. Federal Reserve Bank of Atlanta, Atlanta, August 2001, 907-936.

[10] Berk, J.B. and Green, R.C. (2004) Mutual Fund Flows and Performance in Rational Markets. Journal of Political Economy, 112, 1269-1295.

https://doi.org/10.1086/424739

[11] Lynch, A.W. and Musto, D.K. (2003) How Investors Interpret Past Fund Returns. The Journal of Finance, 58, 2033-2058. https://doi.org/10.1111/1540-6261.00596

[12] Liu, Z.Y. and Yao, Y. (2005) Research on the Phenomenon of "Redemption Puzzle" of Open-End Funds. Securities Market Herald, No. 2, 37-41.

[13] Li, Y. and Yu, J.J. (2004) The External Effect of Open Fund Redemption Mechanism. Research in Finance and Economics, 30, 111-120.

[14] Lu, R., Chen, B.S., Xu, L.B., et al. (2007) Fund Performance and Investors' Choice: 
An Analysis of the Unusual Phenomenon of China's Open-End Fund Redemption. Economic Research, No. 6, 39-50.

[15] Shan, L.W. and Shen, Y. (2013) Fund Marketing and Capital Flow: Empirical Evidence from China Open-End Funds. Research in Finance, No. 1, 192-206.

[16] Yu, H.H., Lu, R. and Xu, L.B. (2014) The Illusion of Investors' Nominal Prices and the Manager's Catering to Meet the Research of Fund Splitting. Economic Research, No. 5, 133-146.

[17] Peng, H., Jiang, X.L. and Wu, H. (2012) The Dynamic Characteristics of "Redeeming Paradox" of Partial Stock Open-End Funds and the Application of Purchase Vision. Management World, No. 6, 60-73.

[18] Luo, Y.L. and Shi, X.H. (2012) An Empirical Study on the Redemption and Redemption of China's Bonded Open-End Funds. Special Economic Zone, No. 5, 106-108.

[19] Fortune, P. (1998) Mutual Funds, Part II: Fund Flows and Security Returns. New England Economic Review, 3-22.

[20] Edelen, R.M. (1999) Investor Flows and the Assessed Performance of Open-End Mutual Funds. Journal of Financial Economics, 53, 439-466. https://doi.org/10.1016/S0304-405X(99)00028-8

[21] Zeckhauser, R., Patel, J. and Hendricks, D. (1991) Nonrational Actors and Financial Market Behavior. Theory and Decision, 31, 257-287.

https://doi.org/10.1007/BF00132995

[22] Li, K. and Lu, R. (2011) Bounded Rationality of Investors and Funds Marketing Strategies-Evidence of Large-Scale Distribution of Funds. Management World, No. 11, 39-48. 